\title{
In MOOCs we Trust: Learner Perceptions of MOOC Quality via Trust and Credibility
}

\author{
https://doi.org/10.3991/ijet.v13i06.8447 \\ Eamon Costello( $\left.{ }^{\square}\right)$, James Brunton, Mark Brown, Laurence Daly \\ Dublin City University, Dublin, Ireland \\ eamon.csotelloddcu.ie
}

\begin{abstract}
In this study we sought to examine MOOC learners' levels of trust in the platforms, institutions, and instructors involved in MOOC design and delivery. We sought to examine what influenced learners' conceptualizations of trust in MOOCs and how this might influence their future intentions towards the related MOOC providers. To this end we examined whether an increase in perceived source credibility of the MOOC increased trusting beliefs of the MOOC learner. Furthermore, we examined whether increases in trusting beliefs of the MOOC learner would lead to an increase in their future trusting intentions. This second question has implications for whether a learner persists in their learning or decides to commit to further study pathways such as paid certificates. In addition to testing these two hypotheses we sought to determine the most significant underlying drivers that learners reported as affecting their trust in MOOCs they undertook. Drawing on concepts of trust from the literature, we adapted and developed a survey instrument and recruited MOOC learners to respond. Following analysis of 76 responses we found a positive correlation between source credibility and learner trust in MOOCs. Further there was also a positive correlation found between trust in MOOCs and learners' professed future intentions. Finally, we determined several component factors of MOOC trust drivers as reported by MOOC learners. Our work holds potential implications for MOOC platform developers, instructors, and designers in signposting areas where MOOC learners have positive and negative experiences of MOOCs, which can in turn influence their future relationship with the MOOC providers.
\end{abstract}

Keywords-MOOCs, Trust, Credibility, Online Learning, Quality

\section{Introduction}

The phenomenon of the MOOC has marched steadily along, continuing to rise despite cycles of hype and hysteria. Reports show that MOOCs continue to grow both in terms of numbers of courses being offered and the total number of learners enrolled on all MOOCs For instance, the increase in the total number of courses has been estimated at 6,850 from over 700 universities in 2016 which would put the total number of people who have enrolled in at least one MOOC at 58 million [1]. The cMOOC and $\mathrm{xMOOC}$ classifications, and other derivatives, show that this is a contested area 
and not a uniform phenomenon. This is evidenced, for example, by two systematic literature reviews of the research into MOOCs that show the breath of this research landscape, and highlight its diversity during the period between 2008 and 2015 [2][3]. In spite of some uncertainty and concern about their true role in education and viable business models, MOOCs appear now to be a mainstay feature of the higher educational landscape. Indeed, the business model and case for MOOCs [4] has gained increasing attention with the arrival of MOOCs for credits, as tasters to fully online degrees, or as freemium services whereby participants pay for extras such as certificates. In this context it is important to examine how MOOC learners may or may not decide to deepen their relationships with MOOC providers. It is important to explore how learners trust or distrust MOOCs and how this might impact on their future intentions towards the providers including in contexts where they may be required to pay for content, services, or certificates. Some research has examined how MOOCS might engender attitudinal change in learners towards specific issues, such as animal welfare [5] or human trafficking [6]. However, no research has been conducted to date on attitudinal change that is not directly related to course objectives. This study sought to address this gap.

Researchers have examined trust and credibility in online environments in a variety of domains, such as trust in ecommerce websites and trust in online medical information. In general, this research aims to model the user's beliefs in some way, usually based on how their pre-existing beliefs are changed through their online interactions and how this may affect their future beliefs and ultimately actions [7][8][9].

Little if any research has been undertaken to date using the well-developed concept of trust in online learning environments, or more specifically to informal online learning such as takes place in MOOCs. This is significant as certain issues that dominate MOOC research would seem to be impacted by the belief model of the learner. The first of these issues is determining how learners might better persist and complete MOOCs. A second question, whether a MOOC learner may be persuaded to engage in a longer, more formal study route or pay for certification, may also be seen as potentially being impacted by learner trust in the MOOC provider.

An important component of trust is credibility, which can be seen as a perceived quality in that it does not reside in an object, person or piece of information [7]. Source credibility has been defined as a two-dimensional concept comprised of perceived expertise (skill) and perceived trustworthiness (morality, goodness). To make a judgement of an item or a person, people tend to evaluate these two elements first and then combine them to make an overall assessment of that item or person's credibility. The research explicated in Ref. [8] extends this model to include a third component, dynamism. Dynamism describes the extent to which a source is "fast, energetic, bold, colourful and confident". It references the way in which a message is delivered [9]. These three components of credibility can be used to examine how a person determines their trust in an entity. This study hence sought to examine the credibility of MOOCs according to the following research question: RQ1: Does perceived credibility of the MOOC increase trusting beliefs of the MOOC learner?

A second question relates to the impact on future behaviour arising from trust levels in the MOOC. In trust based research this impact is known as trusting intentions 
i.e. what will the person do next? Will they buy a product, recommend an item to their friends, disclose information or otherwise make some decision based on the trust beliefs they hold? This led us to the second research question: RQ2: Do trusting beliefs of the MOOC learner increase their trusting intentions towards MOOC providers?

In the methodology section below, we show how we adapted pre-existing research instruments to gather data and analyze constructs relating to trust and intentions. Because this domain is quite different from those in which trust has been examined to date we also wished to more broadly examine trust in MOOCs by asking MOOC learners themselves what affected their trust in MOOCs. To this end we developed the following research question: RQ3: What are key trust drivers according to MOOC learners? The development and use of the instruments to answer the above three research questions will next be outlined.

\section{Methodology}

This current study adopted a similar procedure to that which was performed in Ref. [9]. It framed the MOOC website itself as the message being communicated. The source of the message was the MOOC provider (and also the education institution that provided the course), the receiver of the message was the MOOC learner, and the desired outcome of the providers (i.e. the intended persuasion) was that the learner maintained trusting beliefs, and eventually would intend to further engage with the provider, for example by finishing the course or taking a paid certificate (i.e. would have trusting intentions that lead to behavioural follow-through).

To examine Source Credibility (RQ1) we asked participants to indicate how they felt about the course provider on a scale related to items in three categories: Expertise; Dynamism; and Trustworthiness. Here we followed the scale developed by Ref. [8]. For Expertise participants rated the course provider according to the items: Trained; Experienced; Authoritative; Skilled; Informed; Competent; Knowledgeable; Capable; Successful; Effective; Efficient; Strong; and Orderly (13 items). For Dynamism ratings were of: Fast; Bold; Active; Aggressive; Decisive; and Confident (6 items). For Trustworthiness ratings were made of the items: Safe; Just; Honest; Reasonable; Trustworthy; Good; Sympathetic; Stable; Kind; Rational; Reliable; Reputable; Dependable; Friendly; Sensible; Responsible; and Consistent (17 items). In addition, we asked participants about their Trusting Beliefs relating to course providers according to the constructs of Benevolence, Integrity and Competence, as developed by [4], and used questions adapted from their survey instrument. To solicit information on how leaner trust might influence future behaviour (Trusting Intentions - RQ2) we used the constructs Willingness to Depend (i.e. on a MOOC or MOOC supplied information), to Follow Advice, and Willingness to Make Purchases (i.e. to buy a MOOC certificate or enrol in a fee-paying degree with a MOOC providing institution). The three constructs used are detailed in Table 1: 
Table 1. Trust constructs

\begin{tabular}{|c|c|c|}
\hline Scale & Subscale & Source \\
\hline \multirow{3}{*}{ Source Credibility of MOOC } & Expertise & \multirow{3}{*}{ Ref. [2] } \\
\hline & Dynamism & \\
\hline & Trustworthiness & \\
\hline \multirow{3}{*}{ Trusting Beliefs in MOOC Provider } & Benevolence & \multirow{3}{*}{ Ref. [4] } \\
\hline & Integrity & \\
\hline & Competence & \\
\hline \multirow{3}{*}{ Trusting Intentions towards MOOCs } & Willingness to depend & \multirow{3}{*}{ Ref. [2] } \\
\hline & Follow advice & \\
\hline & Make purchases & \\
\hline
\end{tabular}

Finally, we posed open-ended, free-response questions to participants prompting them to share instances of where they felt high or low levels of trust as a MOOC learner. These questions sought to uncover MOOC specific trust drivers (RQ3). In their work to identify online trust drivers from the perspective of French online consumers, the authors of Ref. [11] identified 15 drivers of online trust categorised as brand equity, layout design, content, expertise, site navigation, cultural markers, trustworthy partnerships, security, ease of contact, personalisation, advice capabilities, community features, usefulness, fulfilment capabilities, and privacy protection. We sought to use categories from this framework to qualitatively code the free text responses that address RQ3.

\section{$3 \quad$ Findings}

Responses to the questionnaire were collected during May and June of 2017 and participants were recruited through social media (Facebook and Twitter). The questionnaire was attempted 74 times of which 61 provided admissible response data for the study.

The survey results corresponding to RQ1 and RQ1 were first analysed for internal reliability of the constructs and then for correlation via scatter plots and statistical tests. The results of the open-ended trust questions (RQ3) were coded manually by a researcher assigning them to one of the 15 categories of Trust Drivers developed in Ref. [11].

Reliability of the scales was checked by measuring the Cronbach Alpha value for each of the scale variable scores. As per Table 2 all Cronbach Alpha values were above 0.8 suggesting good internal consistency reliability of the scales.

Scatterplots were generated to determine the relationship between Source Credibility and Trusting Beliefs (RQ1) and the relationship between Trusting Beliefs and Trusting Intentions (RQ2). Both indicated a positive linear relationship and Pearson Correlation Coefficients were calculated. For RQ1, whether Source Credibility affects Trusting Beliefs, $\mathrm{r}$ was +.511 , a positive correlation, suggesting support for the RQ1 hypothesis, i.e. perceived credibility of the MOOC was associated with trusting be- 
Table 2. Scale reliability

\begin{tabular}{|l|l|c|c|c|c|}
\hline \multicolumn{1}{|c|}{ Scale } & \multicolumn{1}{|c|}{ Subscale } & $\begin{array}{c}\text { Cronbach's } \\
\text { Value }\end{array}$ & $\begin{array}{c}\text { Mean Inter } \\
\text { Item Correla- } \\
\text { tion }\end{array}$ & $\begin{array}{c}\text { Number of } \\
\text { items in the } \\
\text { scale }\end{array}$ & $\begin{array}{c}\text { No. of valid } \\
\text { cases }\end{array}$ \\
\hline \multirow{3}{*}{$\begin{array}{l}\text { Source Credibil- } \\
\text { ity of MOOC }\end{array}$} & Expertise & .978 & .792 & 12 & 39 \\
\cline { 2 - 6 } & Dynamism & .821 & .456 & 6 & 39 \\
\cline { 2 - 6 } & Trustworthiness & .977 & .714 & 17 & 39 \\
\hline \multirow{2}{*}{$\begin{array}{l}\text { Trusting Beliefs } \\
\text { in MOOC } \\
\text { Provider }\end{array}$} & Benevolence & .800 & .593 & 3 & 55 \\
\cline { 2 - 6 } & Integrity & .858 & .604 & 4 & 56 \\
\cline { 2 - 6 } $\begin{array}{l}\text { Trusting Inten- } \\
\text { tions towards } \\
\text { MOOCs }\end{array}$ & $\begin{array}{l}\text { Willingness to } \\
\text { depend }\end{array}$ & .840 & .566 & 4 & 54 \\
\cline { 2 - 6 } & Follow advice & .900 & .533 & 4 & 56 \\
\cline { 2 - 6 } & Make purchases & .802 & .678 & 5 & 54 \\
\hline
\end{tabular}

liefs of the MOOC learner. For RQ2 a correlation coefficient value $r$ of +.603 was found, indicating a positive relationship between the two variables i.e. trusting beliefs of the MOOC learner are associated with higher levels of trusting intentions towards MOOC providers.

\subsection{Trust drivers}

RQ3 attempted to uncover MOOC trust drivers from direct, unstructured user testimony. There were 30 responses to the question that asked users to describe things they felt made them trust or distrust a MOOC or its providers based on their experience. These responses were analyzed and coded to one of the 15 Trust Drivers identified in Ref. [5]. Two further categories were added that are specific to MOOCs: Certification and Instructor Quality. In addition, the category Brand Equity (Quality) was further subdivided into Institution Brand Equity and Platform Brand Equity to examine distinctions between learner trust in MOOC platforms and the university/institution to which the instructor(s) were affiliated. These are detailed in Table 3.

A count of each of the drivers detected and the results are summarized in Figure 1.

Table 3. MOOC Trust Drivers

\begin{tabular}{|l|l|}
\hline $\begin{array}{l}\text { Platform Brand } \\
\text { Equity }\end{array}$ & $\begin{array}{l}\text { Platform brand Awareness, Platform brand liking, Positive platform brand associates, } \\
\text { Platform reputation }\end{array}$ \\
\hline Institution Brand & Institution brand Awareness, Institution brand liking, Positive Institution \\
\hline Equity & brand associates, Institution reputation \\
\hline Layout Design & Quality of graphics and layout, Design elements, Graphical coherence \\
\hline Content Quality & $\begin{array}{l}\text { Course material content, Information quality, Relevance, Reliability, Transparency, } \\
\text { Platform and institution information (e.g. "about us" section) }\end{array}$ \\
\hline Providers' Expertise & $\begin{array}{l}\text { Course quality, Description of the platform's or institution's competencies, Excel- } \\
\text { lence awards, Professionalism, Long-term experience }\end{array}$ \\
\hline Navigation & $\begin{array}{l}\text { Logic of navigation and content presentation, Organisation of content, pages and } \\
\text { menus, Disturbance through pop ups, "How to use" section, website ergonomics }\end{array}$ \\
\hline
\end{tabular}




\begin{tabular}{|l|l|}
\hline Cultural Markers & $\begin{array}{l}\text { National references, Recognition of local tradition and culture, Language translation } \\
\text { facilities, Local phone numbers }\end{array}$ \\
\hline Trustworthy & Institution and Platform partners, Links to partner sites, Partner logos, \\
\hline Partnerships & Partner's network affiliations \\
\hline Security & $\begin{array}{l}\text { Security statements/symbols/seals, Payment procedures and options, Data encryption, } \\
\text { Transparency of processes, "https" address }\end{array}$ \\
\hline Ease of Contact & $\begin{array}{l}\text { Availability of Institution and platform contact information, Page ranking in search } \\
\text { engines, Respond to queries }\end{array}$ \\
\hline Personalisation & $\begin{array}{l}\text { Website feature personalisation, Personal space available, Personal recognition, } \\
\text { Personalised choice options, Interactivity, Confirmation after email contact, Person- } \\
\text { alised during registration }\end{array}$ \\
\hline Advice Capabilities & Virtual course advice, Hotline number, Online/offline help, FAQ section \\
\hline $\begin{array}{l}\text { Community Fea- } \\
\text { tures }\end{array}$ & $\begin{array}{l}\text { Quality and meaningfulness of membership features such as email account, Blogs, } \\
\text { Forums, Availability of other learners' comments/reports, Social media tools and } \\
\text { buttons }\end{array}$ \\
\hline Usefulness & $\begin{array}{l}\text { Efficiency, Search engine, Real time and up to date content, Useful for career and } \\
\text { personal development }\end{array}$ \\
\hline $\begin{array}{l}\text { Fulfilment capabili- } \\
\text { ties }\end{array}$ & $\begin{array}{l}\text { Course guarantees, Cert delivery insurances, Learner rewards, Learner positive } \\
\text { experiences }\end{array}$ \\
\hline Privacy protection & Data protection, User control over personal data, Comprehensible privacy policy \\
\hline Certification & Provision of certification on completion \\
\hline Instructor quality & $\begin{array}{l}\text { Quality of course instructor, Efficiency of instructor, Instructor's capability of engag- } \\
\text { ing with learner }\end{array}$ \\
\hline
\end{tabular}

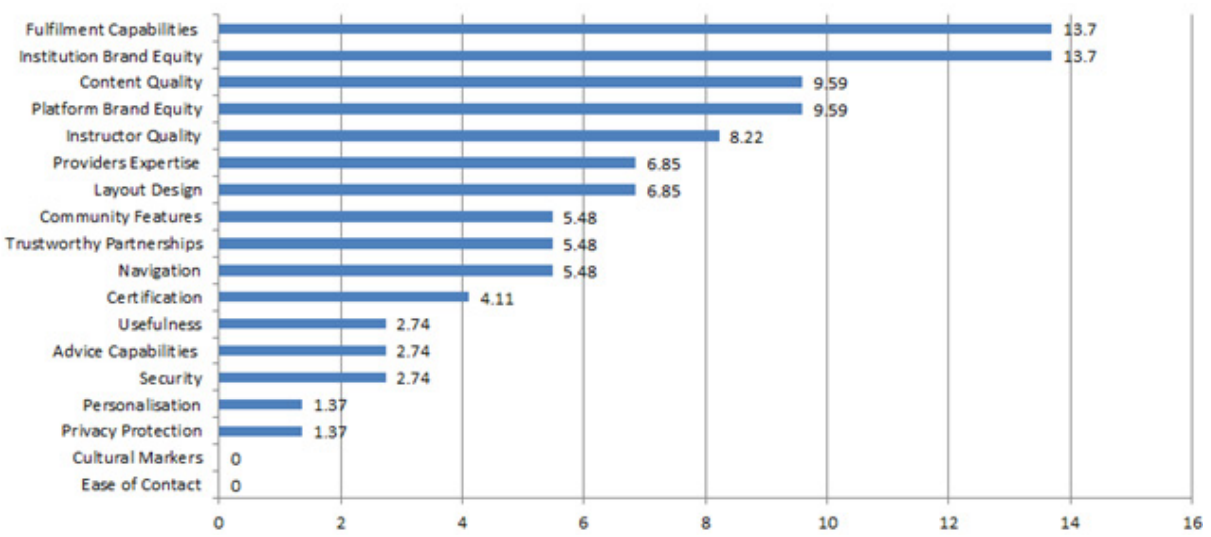

Fig. 1. Percentage of coded trust drivers reported by the respondents

As can be seen from Figure 1 Fulfilment Capabilities and Institution Brand Equity were identified as the most highly rated trust drivers by MOOC learners for MOOC websites and the educational institution that provided them. Both drivers scored 13.7\%. These were followed by Content Quality and Platform Brand Quality, both scored 9.59\%. Cultural Markers, Ease of Contact, Privacy Protection and Personalisation scored the least as trust drivers for the MOOC learners. Table 4 below includes example excerpts of learner responses and their coding for the main trust drivers found. 
Table 4. Examples of participant responses and coding for the main trust factors found

\begin{tabular}{|c|c|c|c|c|c|c|c|}
\hline & 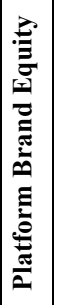 & 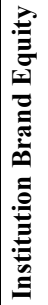 & 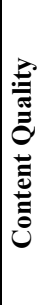 & 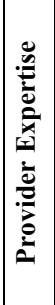 & 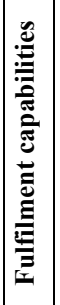 & Ũ & 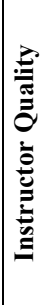 \\
\hline $\begin{array}{l}\text { "As for distrust, I would not feel comfortable acting on all the } \\
\text { information given to me by the course since I know from my own } \\
\text { first-hand experience that some pieces were one-sided histories." }\end{array}$ & & & $*$ & & & & \\
\hline $\begin{array}{l}\text { "trust NIHR site and course good education, distrust experience it } \\
\text { has of primary care led research it's not mentioned so far" }\end{array}$ & & $*$ & $*$ & $*$ & & & \\
\hline $\begin{array}{l}\text { "Trust that Stanford has a reputation to maintain. So, I trust the } \\
\text { entire program" }\end{array}$ & & $*$ & & & & & \\
\hline "My certificate was mailed to me as promised" & & & & & * & $*$ & \\
\hline $\begin{array}{l}\text { "I love the experience and commitment of my instructors, such } \\
\text { humble and learned professionals. Thanks to Coursera" }\end{array}$ & $*$ & & & $*$ & & & $*$ \\
\hline $\begin{array}{l}\text { "It was reliable, challenging and interesting topic. The only thing I } \\
\text { didn't like was there was no option to get a honor code certifi- } \\
\text { cate." }\end{array}$ & & & & & & $*$ & \\
\hline $\begin{array}{l}\text { "I feel confident taking my new course as I have only had positive } \\
\text { experiences with FutureLearn so far. The current educational } \\
\text { provider is well established and regarded and I had no hesitation } \\
\text { in signing up to the course" }\end{array}$ & $*$ & $*$ & & & $*$ & & \\
\hline
\end{tabular}

\section{Discussion and conclusion}

The main contribution of this research to the existing literature is that it has produced findings relating to the concept of learner trust in MOOCs, an area in which there is currently a paucity of research. The findings will guide further research in this field and also point MOOC stakeholders such as providers (designers, instructors, institutions, platforms) to possible ways their MOOC may be engendering or inhibiting development of learner trust in their MOOCs. This may have practical applications such as that known credibility indicators from the literature on web sources [7, 8] appear also to influence learner trust in MOOCs. Moreover, our findings indicate that trust will also affect future learner intentions, known as trusting intentions $[8,10]$. This is important for analyzing, for instance, whether a learner is likely to purchase a certificate based on their learning. This will be important is determining whether MOOCs can overcome the challenges posed of them [12] and transition from 'innovation platforms' [13] to mainstream educational provision. This vein of research will help in determining people discuss and recommend MOOCs such as on social media for example [14]. 
A potential limitation of this study is that the literature does indicate that some trust constructs are not necessarily mutually exclusive and can overlap [7]. We sought to address this with the third of our research questions, which was pursued using qualitative analysis. In this case we used an existing tool from the literature but adapted it to the MOOC context. We make a contribution here by confirming the presence of the majority of trust drivers developed in Ref. [11], but also by identifying new drivers such as the importance of the instructor, institution, and platform. Moreover, our findings contrast with previous ones in domains such as e-commerce retail. For instance, we did not find any evidence of the importance of Cultural Markers nor Ease of Contact, as they are conceptualized in the existing trust literature [11]. Future research in this area could further explore issues suggested by the distribution of trust drivers here to ultimately improve MOOCs for learners.

\section{$5 \quad$ References}

[1] Class Central (2016). [Online]. Available: https://www.class-central.com/report/moocstats-2016/ website. [Accessed: 23- Jan- 2018].

[2] Liyanagunawardena, T. R., Adams, A. A., \& Williams, S. A. (2013). "MOOCs: A systematic study of the published literature 2008-2012". The International Review of Research in Open and Distributed Learning, vol. 14, pp. 202-22 https://doi.org/10.19173/irrodl. v14i3.1455

[3] Veletsianos, G., \& Shepherdson, P. (2016). "A systematic analysis and synthesis of the empirical MOOC literature published in 2013-2015." International Review of Research in Open and Distributed Learning, vol. 17, pp. 198-221. https://doi.org/10.19173/ irrodl.v17i2.2448

[4] Kalman, Y.M., (2014). "A race to the bottom: MOOCs and higher education business models.” Open Learning: The Journal of Open, Distance and e-Learning, vol. 29, pp.5-14. https://doi.org/10.1080/02680513.2014.922410

[5] W. Watson, W. Kim and S. Watson, (2016) "Learning outcomes of a MOOC designed for attitudinal change: A case study of an Animal Behavior and Welfare MOOC", Computers \& Education, vol. 96, pp. 83-93. https://doi.org/10.1016/j.compedu.2016.01.013

[6] S. Watson, J. Loizzo, W. Watson, C. Mueller, J. Lim and P. Ertmer, (2016) "Instructional design, facilitation, and perceived learning outcomes: an exploratory case study of a human trafficking MOOC for attitudinal change", Educational Technology Research and Development, vol. 64, no. 6, pp. 1273-1300. https://doi.org/10.1007/s11423-016-9457-2

[7] Fogg, B. J. (2003). Persuasive technology: Using computers to change what we think and do, San Francisco, CA: Morgan Kaufmann.

[8] Berlo, D. K., Lemert, J. B. and Mertz, R. J. (1969). "Dimensions for evaluating the acceptability of message sources," The public opinion quarterly, vol.33, pp.563-576. https://doi.org/10.1086/267745

[9] Lowry, P., Wilson, D. and Haig, W. (2014). “A Picture is Worth a Thousand Words: Source Credibility Theory Applied to Logo and Website Design for Heightened Credibility and Consumer Trust," International Journal of Human-Computer Interaction, vol.30, pp.63-93. https://doi.org/10.1080/10447318.2013.839899

[10] McKnight, D.H., Choudnury, V. and Kacmar, C.J. (2002). "Developing and validating trust measures for e-Commerce: An integrative typology," Information Systems Research, vol.13, pp.334-359. https://doi.org/10.1287/isre.13.3.334.81 
[11] Bartikowski, B. and Singh, N. (2014). "Doing E-Business in France: Drivers of Online Trust in Business-to-Consumer Websites," Global Business and Organizational Excellence, pp.28-36. https://doi.org/10.1002/joe.21551

[12] Schuwer, R., Jaurena, I. G., Aydin, C. H., Costello, E., Dalsgaard, C., Brown, M., Jansen, D. \& Teixeira, A. (2015) "Opportunities and threats of the MOOC movement for higher education: The European perspective." The International Review of Research in Open and Distributed Learning vol. 16 [Online http://www.irrodl.org/index.php/irrodl/article/ view/2153/3522 [Accessed: Mar. 2, 2018]

[13] Brown, M., Costello, E., Donlon, E. and Giolla-Mhichil, M.N. (2015) "A strategic response to MOOCs: How one European university is approaching the challenge." The International Review of Research in Open and Distributed Learning vol. 16 [Online]. Available: http://www.irrodl.org/index.php/irrodl/article/view/2153/3522 [Accessed: Mar. 2, 2018].

[14] Costello, E., Brown, M., Nair, B., Mhichíl, M. N. G., Zhang, J., \& Lynn, T. (2017) "\#MOOC Friends and Followers: An Analysis of Twitter Hashtag Networks". In: Delgado Kloos C., Jermann P., Pérez-Sanagustín M., Seaton D., White S. (eds) Digital Education: Out to the World and Back to the Campus. EMOOCs 2017. Lecture Notes in Computer Science, vol 10254. Springer, Cham [Online] Available https://link.springer.com/ chapter/10.1007/978-3-319-59044-8 19 [Accessed: Mar. 2, 2018] https://doi.org/10.1007/ 978-3-319-59044-8 19

\section{Authors}

Eamon Costello is currently Head of Open Education in National Institute for Digital Learning (NIDL) at Dublin City University (DCU) and had over a decade of experience in teaching and research in online and blended learning.

James Brunton now Chair/Director of the DCU Conneted BA in Humanities (Psychology Major) in the Open Education Unit, National Institute for Digital Learning and an experienced educator and researcher in online and flexible learning.

Mark Brown is Director of the National Institute for Digital Learning (NIDL) at Dublin City University (DCU). Before taking up Ireland's first Chair in Digital Learning at the start of 2014, Mark was Director of both the National Centre for Teaching and Learning (NCTL) and Distance Education and Learning Futures Alliance (DELFA) at Massey University, New Zealand.

Laurence Daly is a DCU MSc graduate.

Article submitted 16 February 2018. Resubmitted 01 April 2018. Final acceptance 25 April 2018. Final version published as submitted by the authors. 